\title{
SISTEM PENDUKUNG KEPUTUSAN PENENTUAN JURUSAN PADA SISWA SMA 1 HULUK PALIK DESA SUMBER REJO BENGKULU UTARA MENGGUNAKAN PHP DAN MYSQL
}

\author{
Yupianti, Feri Hari Utami \\ 1,2 Dosen Tetap Program Studi Teknik Informatika Fakultas Ilmu Komputer Universitas Dehasen Bengkulu \\ Jl. Meranti Raya No. 32 Kota Bengkulu 38228 Telp. (0736) 22027, 26957 Fax. (0736) 341139; \\ e-mail: yupiantiprana@gmail.com ${ }^{1}$, nedokruan@gmail.com ${ }^{1}$
}

\begin{abstract}
Decision Support System for Determination of Departments in students of State Senior High School 1 Huluk Palik, Sumber Rejo Village, North Bengkulu, using PHP and MYSQL for every second grade increase. The selection of majors is still manual. Teachers have not been able to measure students' abilities in terms of talent and academics. Sometimes the teacher only measures in terms of report cards or grades in class. This of course makes it difficult for students to enter majors according to their talents.

Therefore, a decision support system application was made for student majors at Huluk Palik State Senior High School 1 Bengkulu Utara using the Simple Additive Weighting (SAW) method. This system is designed using the PHP programming language and MySQL database. The resulting application can help North Bengkulu Huluk Palik State Senior High School 1 in student majors.

Results This application can present data quickly and provide information with the calculation process according to the highest normalization results in the results of the decision tree made and in the end can make decisions.

Keywords: Decision Support Systems, Simple Additive Weighting (SAW),Huluk Palik State Senior High School 1, North Bengkulu.
\end{abstract}

Intisari-Sistem Pendukung Keputusan Penentuan Jurusan pada siswa Sekolah Menegah Atas Negeri 1 Huluk Palik Desa Sumber Rejo Bengkulu Utara menggunakan PHP dan MYSQL setiap kenaikan kelas dua. Pemilihan jurusan yang dilakukan masih manual. Guru belum bisa mengukur kemampuan siswa dari segi bakat dan akademik. Kadangkala guru hanya mengukur dari segi nilai rapor atau ranking di kelas. Hal ini tentunya menyulitkan siswa untuk masuk ke jurusan sesuai dengan bakatnya.

Oleh karena itu, dibuat aplikasi sistem pendukung keputusan untuk penjurusan siswa di Sekolah Menegah Atas Negeri 1 Huluk Palik Bengkulu Utara dengan menggunakan metode Simple Additive Weighting (SAW). Sistem ini dirancang menggunakan Bahasa Pemrograman PHP dan Database MySQL. Aplikasi yang dihasilkan dapat membantu Sekolah Menegah Atas Negeri 1 Huluk Palik Bengkulu Utara dalam penjurusan siswa.

Hasil Aplikasi ini dapat menyajikan data secara cepat dan memberikan informasi dengan proses perhitungan sesuai hasil normalisasi tertinggi pada hasil pohon keputusan yang dibuat dan pada akhirnya bisa mengambil keputusan.

Kata Kunci: Sistem Pendukung Keputusan, Simple Additive Weighting (SAW).

\section{I.PENDAHULUAN}

Perkembangan ilmu pengetahuan dan teknologi telah membawa perubahan di hampir semua aspek kehidupan manusia dimana berbagai permasalahan hanya dapat dipecahkan kecuali dengan upaya penguasaan dan peningkatan ilmu pengetahuan dan teknologi.

Kemajuan teknologi sudah mengalami perkembangan yang pesat, masih ada berbagai instansi pendidikan atau sekolah yang belum mengkomputerisasikan sistem penjurusan dan masih dilakukan secara manual. Hal ini menyebabkan keterlambatan dalam pembuatan laporan yang berkaitan dengan lambatnya informasi sehingga akan banyak menyita waktu dan pengolahan data terhadap kesalahan lebih besar.

Pada SMA 1 Huluk Palik Bengkulu Utara, pemilihan jurusan yang dilakukan masih manual. Guru belum bisa mengukur kemampuan siswa dari segi bakat dan akademik. Kadangkala guru hanya mengukur dari segi nilai rapor atau ranking di kelas. Hal ini tentunya menyulitkan siswa untuk masuk ke jurusan sesuai dengan bakatnya. Oleh karena itu, dibutuhkan sistem penjurusan pada SMA 1 Huluk Palik Bengkulu Utara untuk membantu sekolah dalam menentukan jurusan siswa yang sesuai dengan bakat dan akademik masing-masing siswa.

Dari itu peneliti membuat Sistem Pendukung Keputusan Penentuan Jurusan pada Siswa SMA 1 Huluk Palik Desa Sumber Rejo Bengkulu Utara Menggunakan PHP dan MySQL

\section{II.TINJAUAN PUSTAKA}

\section{A. Sistem Pendukung Keputusan}

Menurut Ariani (2015:2), Sistem pendukung keputusan merupakan sistem informasi interaktif yang menyediakan informasi, pemodelan, dan pemanipulasian data. Sistem itu digunakan untuk membantu pengambilan keputusan dalam situasi yang semiterstruktur dan situasi yang tidak terstruktur, di mana tak seorang pun tahu secara pasti bagaimana keputusan seharusnya dibuat. 
Konfigurasi Sistem Pendukung Keputusan

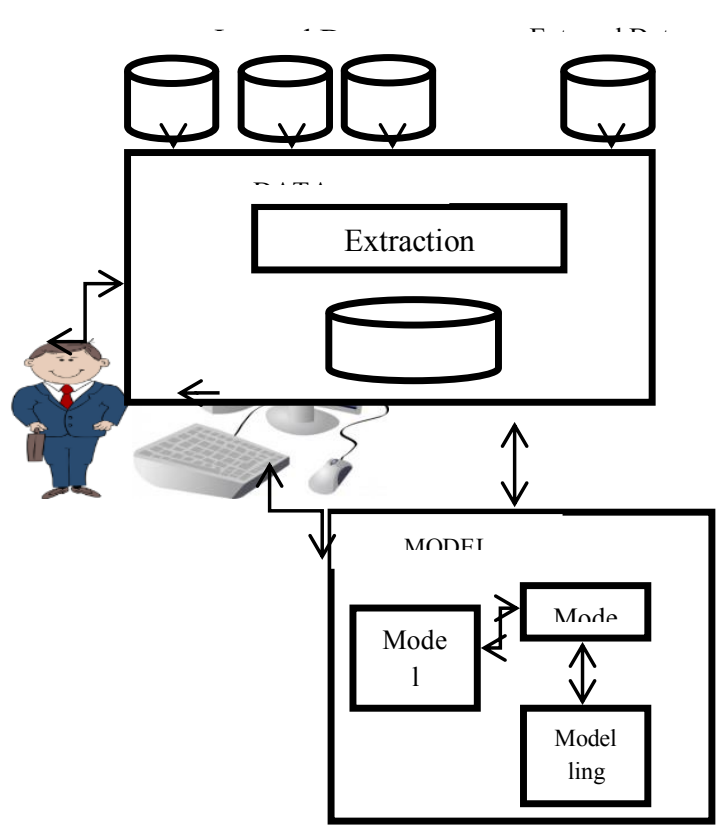

Gambar 1 Konfigurasi Sistem Pendukung Keputusan

\section{B. Metode Simple Additive Weighting (SAW)}

Menurut Pratiwi (2013:4), metode Simple Additive Weighting (SAW) terdapat skor yang diberikan sesuai kontribusi di setiap pilihan kriteria. Dua kriteria dengan perbedaan skala ukuran tidak dapat ditambahkan yang umumnya menggunakan sistem skala numerik. Normalisasi dilakukan untuk penambahan dari perbedaan kriteria di setiap alternatif. Total skor disetiap alternatif diestimasi dengan banyaknya nilai normalisasi untuk setiap kriteria dengan bobot kepentingan dan kemudian menjumlahkan hasil dari semua kriteria dalam permasalahan. Konsep dasar SAW adalah mencari penjumlahan terbobot dari rating kinerja pada setiap alternatif pada semua atribut. Metode SAW membutuhkan proses normalisasi matriks keputusan (X) ke suatu skala yang dapat diperbandingkan dengan semua rating alternatif yang ada. Formula untuk melakukan normalisasi tersebut adalah sebagai berikut:

$$
r i j\left\{\begin{array}{l}
\frac{x i j}{M a x X i j} \\
\quad \text { jika j adalah atribut keuntungan (Benefit) } \\
\frac{M i n X i j}{X i j}
\end{array}\right.
$$

Keterangan :

Rij : Nilai rating kinerja ternormalisasi

Xij : Nilai atribu yang dimiliki dari setiap Kriteria

Max Xij:Nilai terbesar dari setiap Kriteria

Min Xij: Nilai terkecil dari setiap Kriteria

Benefit : jika nilai terbesar adalah terbaik

Cost : jika nilai terkecil adalah terbaik

Dimana rij adalah rating kinerja ternormalisasi dari alternatif $\mathrm{Ai}$ pada atribut $\mathrm{Cj} ; \quad \mathrm{i}=1,2, \ldots, \mathrm{m}$ dan $\mathrm{j}=1,2, \ldots . ., n$. Nilai preferensi untuk setiap alternatif

(Vi) diberikan sebagai :

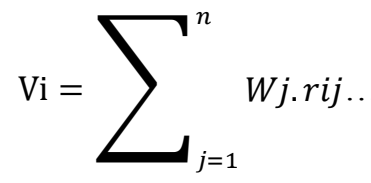

Keterangan :

Vi : Rangking untuk setiap alternatif

$\mathrm{Wj} \quad$ : Nilai bobot dari setiap criteria

Rij : Nilai rating kinerja ternormalisasi

Nilai Vi yang lebih besar mengindikasikan bahwa alternative Ai lebih terpilih.

Langkah-langkah dalam menentukan metode SAW :

1. Menentukan Kriteria yang akan dijadikan acuan dalam pengambilan keputusan, misalnya $\mathrm{C} 1$.

2. Menentukan rating kecocokan setiap alternatif pada setiap Kriteria.

3. Menentukan matriks keputusan berdasarkan Kriteria (C1), kemudian melakukan normalisasi matriks berdasarkan persamaan yang disesuaikan dengan jenis atribut (atribut keuntungan ataupun atribut biaya) sehingga matriks ternormalisasi R.

4. Hasil akhir diperoleh dari proses perangkingan yaitu penjumlahan dari perkalian matriks ternormalisasi $\mathrm{R}$ dengan vector bobot preferensi sehingga diperoleh nilai terbesar yang dipilih sebagai alternatif terbaik misalnya (A1). 


\section{Pengertian PHP}

Menurut tim EMS (2012:61) PHP adalah bahasa pelengkap HTML yang memungkinkan dibuatnya aplikasi dinamis yang memungkinkan adanya pengolahan data dan pemrosesan data. Semua sintax yang diberikan akan sepenuhnya dijalankan pada server sedangkan yang dikirimkan ke browser hanya hasilnya saja. Kemudian merupakan bahasa berbentuk script yang ditempatkan dalam server dan diproses di server. Hasilnya akan dikirimkan ke client, tempat pemakai menggunakan browser.

Program PHP dapat diaktifkan dengan menggunakan paket PHP berbasis Open Source yaitu XAMPP. XAMPP merupakan paket PHP yang dikembangkan oleh komunitas Open Source. Xammp menyediakan program Apache, MySQL, PHP dan phpMyAdmin.

\section{Pengertian MySQL}

Menurut Kurniawan (2010:16), MySQL merupakan suatu jenis database server yang sangat terkenal. MySQL termasuk jenis RDBMS (Relational Database Manajement System). MySQL mendukung bahasa pemrograman $\mathrm{PH}$, bahasa permintaan yang terstruktur, karena pada penggunaannya SQL memiliki berberapa aturan yang telah distandarkan oleh asosiasi yang bernama ANSI.MySQL merupakan RDBMS (Relational Database Management System) server. RDBMS adalah program yang memungkinkan pengguna database untuk membuat, mengelola, dan menggunakan data pada suatu model relational.

\section{METODOLOGI PENELITIAN}

\section{A. Metode Penelitian}

Metode yang digunakan dalam penelitian ini adalah metode pengembangan sistem dalam Sistem Pendukung Keputusan untuk menentukan jurusan di SMA 1 Hulu Palik menggunakan metode SAW.

B.Penerapan Metode Simple Additive Weighting (SAW)

Dalam metode Simple Additive Weighting (SAW) terdapat kriteria yang akan dijadikan bahan perhitungan. Hal itu dimaksud untuk menentukan siapa yang akan terseleksi sebagai siswa yang tidak dapat masuk ke jurusan Ilmu Pengetahuan Alam (IPA) dan Ilmu
Pengetahuan Sosial (IPS). Adapun kreteria yang menjadi bahan pertimbangan pihak sekolah adalah sebagai berikut $\mathrm{C} 1=$ Nilai rata-rata IPA

$$
\text { Yang terdiri dari mata pelajaran sebagai }
$$

berikut :
a. Matematika
b. Fisika
c. Kimia
d. Biologi

1. $\mathrm{C} 2=$ Nilai rata-rata IPS

Yang terdiri dari mata pelajaran sebagai berikut :
a. Sejarah
b. Sosiologi
c. Geografi
2. $\mathrm{C} 3=$ Nilai bakat IPA

Untuk nilai bakat IPA diambil dari jawaban soalsoal IPA sebanyak 10 soal.

3. $\mathrm{C} 4=$ Nilai bakat IPS

Untuk nilai bakat IPSA diambil dari jawaban soal-soal IPS sebanyak 10 soal.

Dari data dibawah ini, maka proses untuk menentukan total nilai dan jurusan masing-masing siswa adalah sebagai berikut :

\section{Tabel 3.5 Data Nilai Siswa}

\begin{tabular}{|c|c|c|c|c|}
\hline Siswa & $\begin{array}{c}\text { C1(Rata- } \\
\text { rata IPA) }\end{array}$ & $\begin{array}{c}\text { C2(Rata- } \\
\text { rata IPS) }\end{array}$ & $\begin{array}{c}\text { C3(Bakat } \\
\text { IPA) }\end{array}$ & $\begin{array}{c}\text { C4(Bakat } \\
\text { IPS) }\end{array}$ \\
\hline lis Suryani & 80,25 & 73 & 75 & 60 \\
\hline $\begin{array}{c}\text { Alifa Nur } \\
\text { Haliza }\end{array}$ & 83,75 & 77,67 & 70 & 65 \\
\hline Geri Pratama & 84,75 & 79,33 & 75 & 65 \\
\hline $\begin{array}{c}\text { Yongki } \\
\text { Ibrahim }\end{array}$ & 75,25 & 86 & 70 & 85 \\
\hline Abastian & 69,25 & 78,33 & 60 & 70 \\
\hline
\end{tabular}

\section{Langkah 1 :}

a. Menghitung vektor bobot

b. Matrik Terakhir menentukan nilai preverensi untuk setiap alternatif

Langkah 2 :

Normalisasi matriks $\mathrm{X}$ menggunakan rumus :

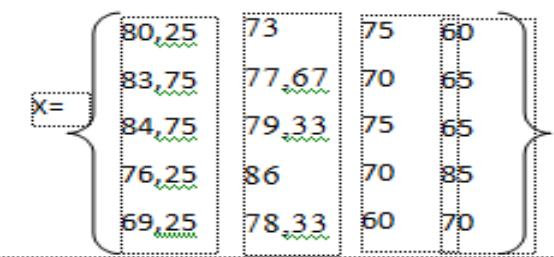


Rij $=\frac{X i j}{M a x X i j}$

\section{a. Iis Suryani}

$$
\begin{aligned}
& \mathrm{R}_{\text {iis Suryani(Rata-rata) }}=\frac{80,25}{\max \{80.25,73\}}=\frac{80.25}{80.25}=1 \\
& \mathrm{R}_{\text {iis Suryani(Rata-rata) }}=\frac{73}{\max \{80,63.3\}}=\frac{73}{80.25}=0,90 \\
& \mathrm{R}_{\text {iis Suryani(Bakat) }}=\frac{75}{\max \{75,60\}}=\frac{75}{75}=1 \\
& \mathrm{R}_{\text {iis Suryani(Bakat) }}=\frac{75}{\max \{75,60\}}=\frac{75}{60}=0,8
\end{aligned}
$$

Mengalikan matriks ternormalisasi (R) dengan nilai bobot $(\mathrm{W}=0,6$ dan 0,4$)$.

$$
\begin{gathered}
\mathrm{R}=\left\{\begin{array}{cc}
1 & 1 \\
0,90 & 0,8
\end{array}\right\} \\
\mathrm{V}(\mathrm{IPA})=(1)(0,6)+(1)(0,4) \\
=1 \\
\mathrm{~V}(\mathrm{IPS})=(0,90)(0,6)+(0,8)(0,4) \\
=0,86
\end{gathered}
$$

Dilihat dari hasil $\mathrm{V}$, maka nilai tertinggi adala IPA. Oleh karena itu Iis Suryani masuk ke jurusan IPA.

\section{b. Alifa Nur Haliza}

$$
\begin{aligned}
& \mathrm{R}_{\text {Alifa Nur Haliza (Rata-rata) }}=\frac{83,75}{\max \{83,75,77,67\}}= \\
& \frac{83,75}{83,75}=1 \\
& \mathrm{R}_{\text {Alifa Nur Haliza (Rata-rata) }}=\frac{77,67}{\max \{83,75,77,67,\}}= \\
& \frac{77,67}{83,75}=0,927 \\
& \mathrm{R}_{\text {iis Suryani(Bakat) }}=\frac{70}{\max \{70,65\}}=\frac{70}{70}=1 \\
& \mathrm{R}_{\text {iis Suryani(Bakat) }}=\frac{65}{\max \{70,65\}}=\frac{65}{70}=0,928
\end{aligned}
$$

Mengalikan matriks ternormalisasi (R) dengan nilai bobot $(\mathrm{W}=0,6$ dan 0,4$)$.

$$
\begin{aligned}
& \mathrm{R}=\left\{\begin{array}{ll}
1 & 1 \\
0,927 & 0,928
\end{array}\right\} \\
& \mathrm{V}(\mathrm{IPA})=(1)(0,6)+(1)(0,4) \\
& =1 \\
& \mathrm{~V}(\mathrm{IPS})=(0,927)(0,6)+(0,928)(0,4) \\
& =0,927
\end{aligned}
$$

Dilihat dari hasil $\mathrm{V}$, maka nilai tertinggi adala IPA. Oleh karena itu Alifa Nurhaliza masuk ke jurusan IPA.

\section{c. Geri Pratama}

$\mathrm{R}_{\text {Geri Pratama (Rata-rata) }}=\frac{84,75}{\max \{84.75,79.33\}}=\frac{84,75}{84,75}=1$

$\mathrm{R}_{\text {Geri Pratama (Rata-rata) }}=\frac{79,33}{\max \{84.75,79.33\}}=$

$\frac{79,33}{84,75}=0,936$

$\mathrm{R}_{\text {Geri Pratama (Bakat) }}=\frac{75}{\max \{75,65\}}=\frac{75}{75}=1$

$\mathrm{R}_{\text {Geri Pratama (Bakat) }}=\frac{65}{\max \{75,65\}}=\frac{65}{75}=0,86$

Mengalikan matriks ternormalisasi (R) dengan nilai bobot $(\mathrm{W}=0,6$ dan 0,4$)$.

$$
\begin{aligned}
& R=\left\{\begin{array}{ll}
1 & 1 \\
0,936 & 0,86
\end{array}\right\} \\
& \mathrm{V}(\mathrm{IPA})=(1)(0,6)+(1)(0,4) \\
& =1 \\
& \mathrm{~V}(\mathrm{IPS})=(0,936)(0,6)+(0,86)(0,4) \\
& =0,908
\end{aligned}
$$

Dilihat dari hasil $\mathrm{V}$, maka nilai tertinggi adala IPA. Oleh karena itu Geri Pratama masuk ke jurusan IPA.

\section{d. Yongki Ibrahim}

$$
\begin{array}{ll}
\mathrm{R}_{\text {Yongki Ibrahim (Rata-rata) }} & =\frac{76,25}{\max \{76.25,86\}}= \\
\frac{762,5}{86}=0,875 & =\frac{86}{\max \{76.25,86\}}=\frac{86}{86}=1 \\
\mathrm{R}_{\text {Yongki Ibrahim (Rata-rata) }} & =\frac{70}{\max \{70,85\}}=\frac{70}{85}=0.82 \\
\mathrm{R}_{\text {Yongki Ibrahim (Bakat) }} & =\frac{85}{\max \{70,85\}}=\frac{85}{85}=1 \\
\mathrm{R}_{\text {Yongki Ibrahim (Bakat) }} &
\end{array}
$$

Mengalikan matriks ternormalisasi (R) dengan nilai bobot $(\mathrm{W}=0,6$ dan 0,4$)$.

$$
\begin{aligned}
& \left\{\begin{array}{ll} 
& \\
0,875 & 0,82 \\
1 & 1
\end{array}\right\} \\
& \mathrm{V}(\mathrm{IPA}) \quad=(0,875)(0,6)+(0,82)(0,4) \\
&
\end{aligned}
$$




$$
\begin{gathered}
\mathrm{V}(\mathrm{IPS})=(1)(0,6)+(1)(0,4) \\
=1
\end{gathered}
$$

Dilihat dari hasil $\mathrm{V}$, maka nilai tertinggi adala IPS. Oleh karena itu Yongki Ibrahim masuk ke jurusan IPS.

\section{e. Abastian}

$$
\begin{aligned}
& \mathrm{R}_{\text {Abastian (Rata-rata) }}=\frac{69,25}{\max \{69,25,78.33\}}=\frac{69,25}{78,33}=0,88 \\
& \mathrm{R}_{\text {Abastian (Rata-rata) }}=\frac{78,33}{\max \{69,25,78.33\}}=\frac{78,33}{78,33}=1 \\
& \mathrm{R}_{\text {Abastian (Bakat) }}=\frac{60}{\max \{60,70\}}=\frac{60}{70}=0.85 \\
& \mathrm{R}_{\text {Abastian (Bakat) }}=\frac{70}{\max \{60,70\}}=\frac{70}{70}=1
\end{aligned}
$$

Mengalikan matriks ternormalisasi (R) dengan nilai bobot $(\mathrm{W}=0,6$ dan 0,4$)$.

$$
\begin{aligned}
& \mathrm{R}=\left\{\begin{array}{lc}
0,88 & 0,85 \\
1 & 1
\end{array}\right\} \\
& \mathrm{V}(\mathrm{IPA})=(0,88)(0,6)+(0,85)(0,4) \\
& =0,873 \\
& \mathrm{~V}(\mathrm{IPS})=(1)(0,6)+(1)(0,4) \\
& =1
\end{aligned}
$$

Dilihat dari hasil V, maka nilai tertinggi adala IPS. Oleh karena itu Abastin masuk ke jurusan IPS.

Dilihat dari hasil V kelima sampel, maka siswa yang masuk jurusan IPA adalah Iis Suryani, Alifa Nur Haliza dan Geri Pratama. Dan yang masuk jurusan IPS adalah Yongki Ibrahin dan Abastian.

\section{IV.HASIL DAN PEMBAHASAN}

\section{A.Hasil}

Sistem Pendukung Keputusan penentuan jurusan pada Siswa SMA 1 Huluk Palik Desa Sumber Rejo Bengkulu Utara ini diimpelementasikan dengan menggunakan bahasa pemrograman PHP dan Database MySQL. Adapun rancangan tampilan masing-masing menu adalah sebagai berikut :

\section{B.Tampilan Halaman Menu Login Admin}

Tampilan login merupakan tampilan awal pada halaman menu. Pada tampilan menu utama atau login ini admin harus melakukan login untuk dapat mengakses halaman berikutnya.

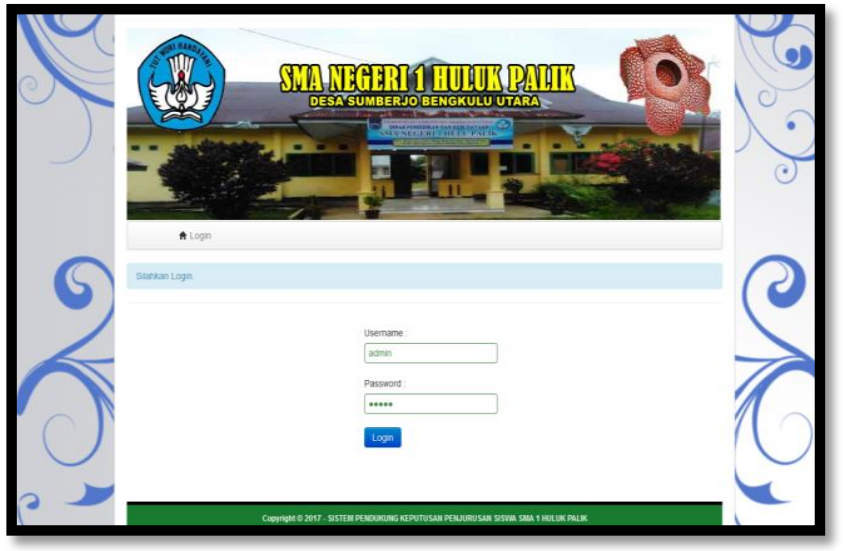

\section{Gambar 2. Tampilan Halaman Menu Login}

\section{B.Tampilan Menu Input Data Siswa}

Halaman ini merupakan halaman yang digunakan oleh admin untuk memasukkan data siswa ke sistem. Disamping itu halaman ini juga digunakan oleh admin untuk mengkoreksi serta menghapus data siswa.

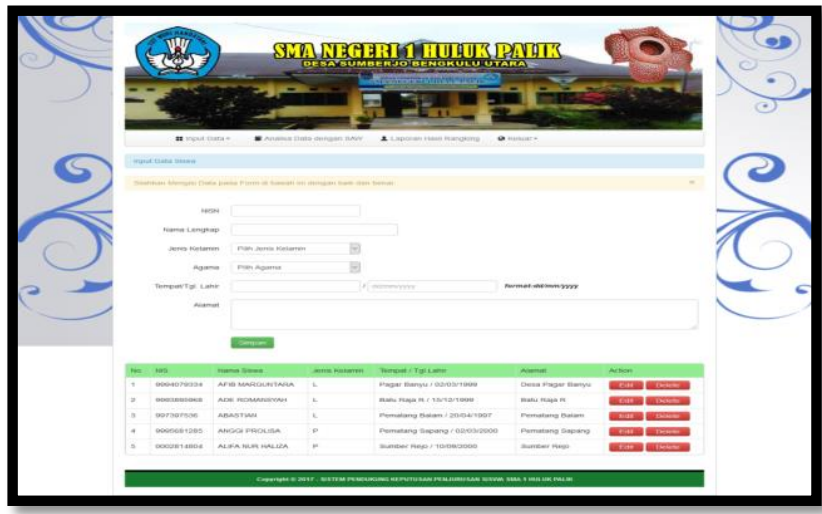

Gambar 3 Tampilan Input Data Siswa

\section{C.Tampilan Data Kriteria}

Halaman ini berisi informasi temtang kriteria yang digunakan dalam aplikasi istem Pendukung Keputusan penentuan jurusan pada Siswa SMA 1 Huluk Palik Desa Sumber Rejo Bengkulu Utara ini. Yang mana kriteria yang digunakan terdiri dari nilai rata-rata dan nilai bakat. Nilai rata-rata dibagi menjadi dua bagian yaitu nilai ratarata IPA dan nilai rata-rata IPS. Kemudian nilai bakat juga dibagi menjadi dua bagian yaitu bakat IPA dan bakat IPS. 


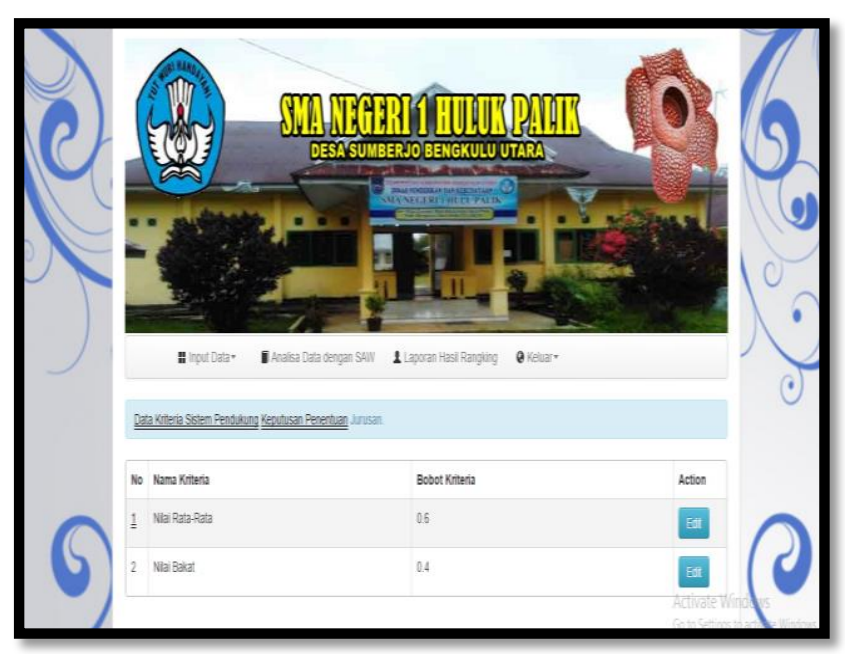

Gambar 4 Tampilan Input Data Kriteria.

\section{D.Tampilan Halaman Penilaian}

Halaman ini merupakan halaman yang digunakan oleh admin untuk memsukkan data penilain siswa dalam menentukan penjurusan. Pada halaman ini nomor induk siswa dapat dipilih secara otamatis. Kemudian setelah memilih siswa yang akan dianalisa, selanjutnya nilai masing-masing dimasukkan pada form yang telah disediakan.

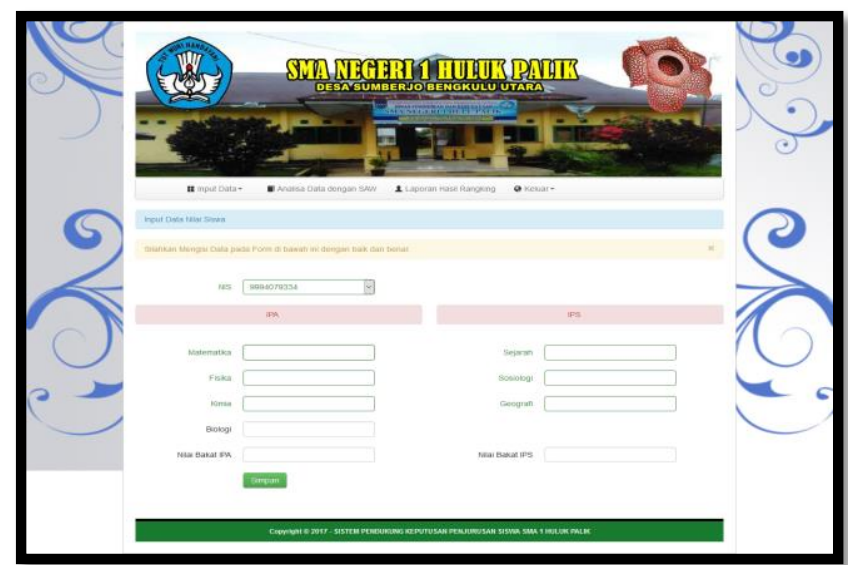

Gambar 5. Rancangan Input Data Nilai Siswa

\section{E. Rancangan Proses SAW}

Pada halaman ini semua nilai masing-masing yang sudah diinputkan berdasarkan kriteria yang ada akan diproses. Nilai-nilai tersebut akan tampil otomatis di halaman ini. Khususnya untuk nilai rata-rata IPA dan IPS akan muncul otomatis berdasarkan nilai masing-masing mata pelajaran yang dimasukkan di form penilaian siswa. Kemudian untuk memproses nilai-nilai ini klik butoon "Proses" maka sistem akan memproses secara otomatis berdasarkan perhitungan dengan menggunakan metode Simple Additive Weighting (SAW).

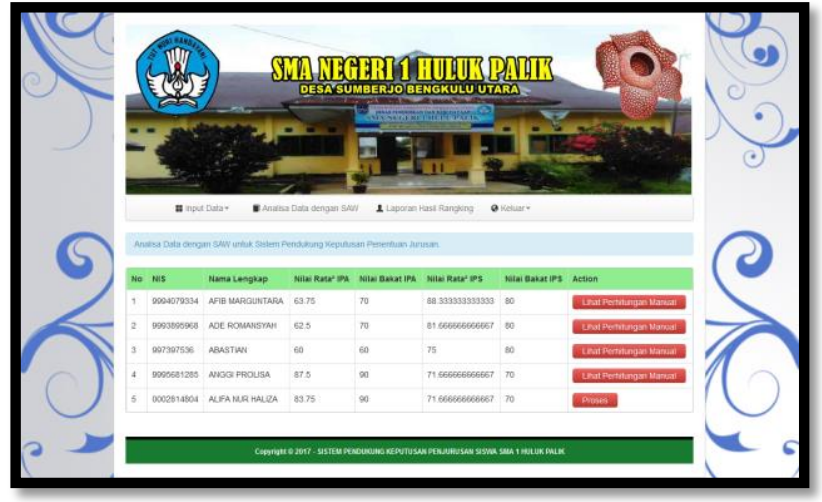

Gambar 6. Tampilan Analisa Data Dengan SAW

Kemudian setelah dilakukan proses di atas, maka secara otomatis sistem menampilkan jurusan siswa dengan melihat nilai tertinggi dari masing-masing kriteria jurusan.

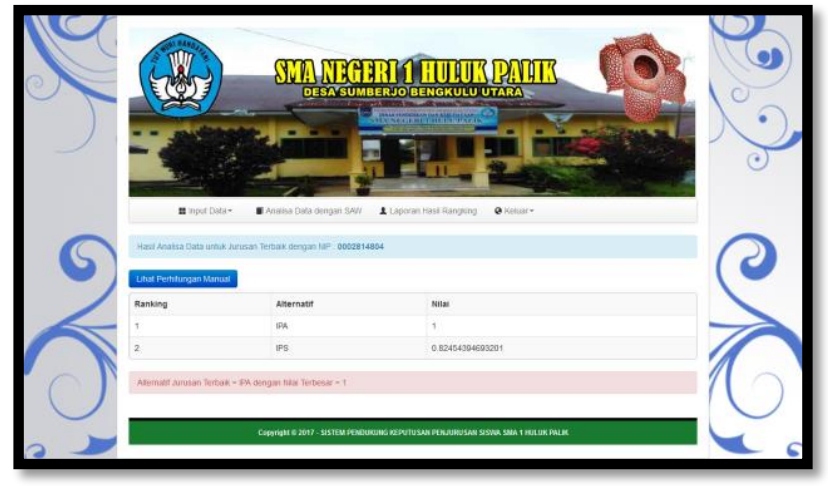

Gambar 7. Hasil penjurusann

Kemudian data yang sudah di proses menggunakan metode Simple Additive Weighting (SAW) tersebut dapat dilihat hasil perhitungannya.

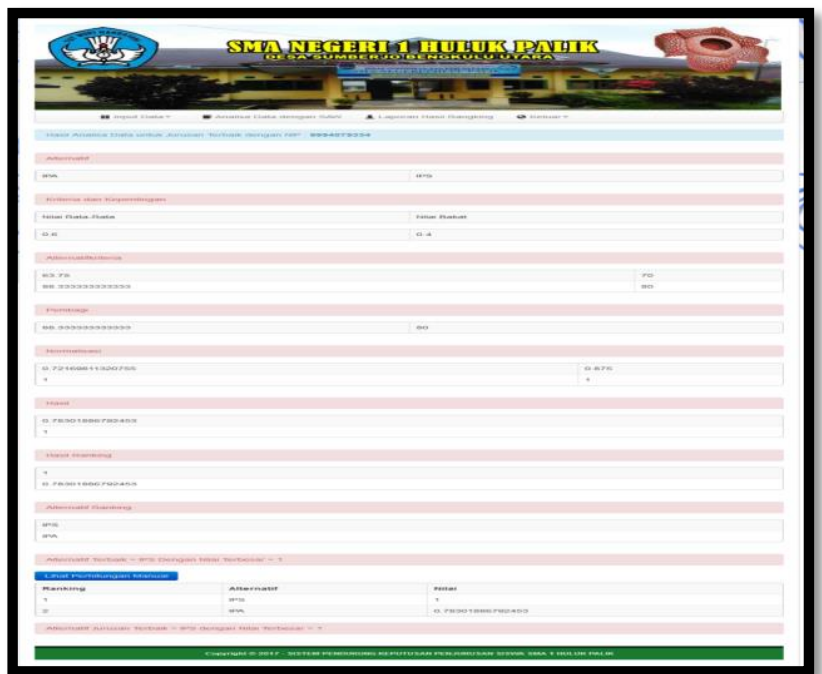

Gambar 8. Hasil Perhitungan 


\section{F.Tampilan Halaman Laporan}

Halaman ini berisi laporan penjurusan siswa. Yang mana laporan ini dapat dicetak. Adapun tampilan halaman laporan.

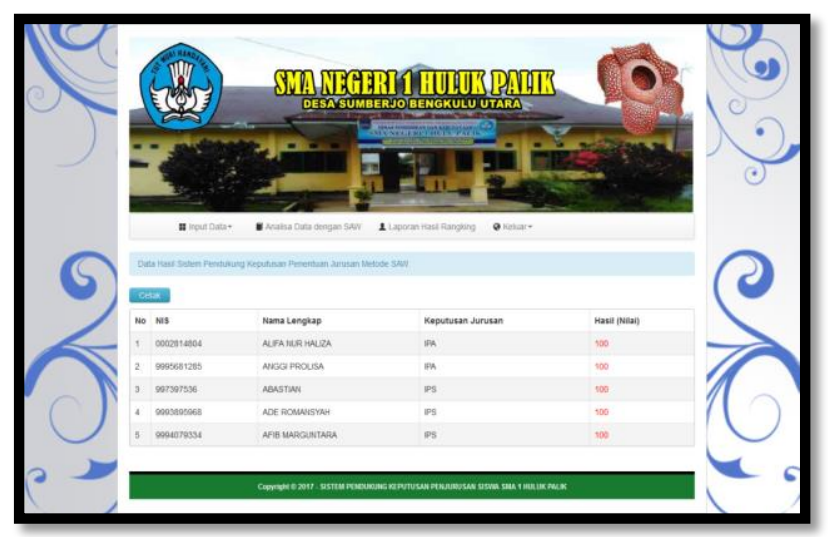

Gambar 9 Tampilan Hasil Halaman Laporan

\section{PENUTUP}

\section{Kesimpulan}

Dari uraian masalah di atas, serta berdasarkan analisa dari bab-bab yang ada, maka dapat ditarik kesimpulan sebagai berikut:

1. Aplikasi sistem pendukung keputusan penentuan jurusan pada siswa SMA 1 Huluk Palik Desa Sumber Rejo Bengkulu Utara ini di rancang menggunakan Bahasa pemprograman PHP. Sistem dapat memberikan kemudahan bagi SMA 1 Huluk Palik Desa Sumber Rejo Bengkulu Utara dalam menentukan keputusan penjurusan siswa di SMA 1 Huluk Palik Desa Sumber Rejo Bengkulu Utara.

2. Aplikasi ini dapat menyajikan data secara cepat dan memberikan informasi dengan proses perhitungan sesuai hasil normalisasi tertinggi pada hasil pohon keputusan yang dibuat dan pada akhirnya bisa mengambil keputusan.

3. Aplikasi ini dapat membantu sebagai penujang keputusan dalam mengambil keputusan dalam menentukan keputusan penjurusan siswa di SMA 1 Huluk Palik Desa Sumber Rejo Bengkulu Utara.

\section{B. Saran}

Dari kesimpulan di atas maka dapat dikemukakan beberapa saran yang diharapkan untuk pengembangan ke depannya dengan beberapa saran dan dapat menjadi bahan pertimbangan lebih lanjut. Adapun saran-saran yang ingin disampaikan adalah:

1. Dari kajian diatas, penulis mengharapkan adanya penelitian lanjutan, karena ada beberapa bagian yang tidak di bahas, karena keterbatasan waktu dan batasan dari permasalahan yang telah ditetapkan sebelumnya.

2. Untuk penelitian berikutnya bisa ditambahkan lagi elemen-elemen yang lebih baik karena sistem ini masih ada kekurangannya.

Diperlukan maintenance terhadap program aplikasi yang telah dibuat, supaya dapat digunakan secara berkelanjutan selama kebutuhan terhadap informasi.

\section{DAFTAR PUSTAKA}

[1] Afriyanti, M., 2013., Sistem Pendukung Keputusan Penentuan Bonus Dan Kenaikan Gaji Karyawan Di PT. Priz Travel Dengan Metode Simple Additive Weighting (SAW), Pepustakaan Pusat STTI Tanjung Pinang, JBPTSTTIPPP

[2] Chun, Y., Huang, Y.Y. dan Wang, Z.Q., 2009, TopsisAHP Simulation Method and its Application in Operational Capabilty Evaluation, IEEE Journal \& Magazines, 978-1-4244-2723-9/09.

[3]Costa, D.A., 2011, Sistem Pendukung Keputusan Penerimaan Dosen Berbasi Web Dengan Metode Simple Additive Weighting (Studi Kasu pada Instituto Proffissional De Cannosa Dili Timor Leste)., Tesis, Program Studi S2 Ilmu Komputer, Fakultas atematika dan Ilmu Pengetahuan Alam, Universitas Gajah Mada, Yogyakarta

[4]Dalalah, D., Al-Oqla, F., Hayajneh, M., 2010, Application of the Analytic Hierarchy Process (AHP) in Multi-Criteria Analysis of The Selection of Cranes, Jordan Journal of Mechanical and Industrial Engineering (JJMIE), Volume 4, Number 5, November 2010, Pages 567-578, ISSN : 1995-6665, Jordan University of Science and Technology.

[5]Dong, C., 2011, Innovation capacity Apparaisal of Junior College EngineeringStudents Based on AHP TOPSIS, IEEE Journal \& Magazines, 978-1-

4244-2723-9/09 
[6] Sitorus, Lamhot, Drs. M.Kom. 2015 Algoritma dan Pemrograman. Yogyakarta: Penerbit Andi.

[7] Soeherman, Bonnie dan Pinontoan, Marion. 2008. Designing Information System, Concepts \& Cases with Visio. Jakarta: Penerbit PT. Elex Media Komputindo. 